\title{
RESPONSE OF COTTON CV GIZA 86 TO FOLIAR APPLICATION OF PHOSPHORUS AND MEPIQUAT CHLORIDE UNDER FERTILE SOIL CONDITION
}

\author{
GEBALY, SANAA G. AND A. E. EL-GABIERY
}

Cotton Research Institute, ARC, Giza. Egypt

(Manuscript received 3 July 2011)

\begin{abstract}
Two field experiments were carried out at Gemmeiza Agricultural Research station, El-Gharbia Governorate during 2008 and 2009 seasons. The investigation aimed to study the effect of foliar application of phosphoric acid $\left(\mathrm{P}_{2} \mathrm{O}_{5} 85 \%\right)$ at $1,1.5$ and 2 $\mathrm{cm}^{3} / \mathrm{L}$ and spraying mepiquat chloride (Pix) $50 \mathrm{~g} /$ fed. at 1,2 and 3 $\mathrm{cm}^{3} / \mathrm{L}$ at pinhead square, start of flowering and peak of flowering stage on the productivity of cotton plants (Giza 86 ).

The obtained results showed that, in comparison with the control, phosphorus and Pix tended to decrease plant height. On the other hand, these treatments, in general increased number of fruiting branches / plant, number of open bolls / plant, boll weight, seed cotton yield per fed., relative fruitfulness (R.F.), earliness \%, also increased leaves contents of chlorophyll $a, b$ and $(a+b)$, carotenoids, total phenol and poly phenol as well as oil and protein contents in seeds. These treatments did not affect lint \%, seed index and fiber properties in both seasons.

The highest values obtained from foliage spraying of cotton plants with (PHX $1.5 \mathrm{~cm}^{3} / \mathrm{L}$ phosphorus and $2 \mathrm{~cm}^{3} / \mathrm{L}$ Pix) at flowering stage improved performance and yield of cotton plants.

Key words: Cotton, phosphoric acid, mepiquat chloride, growth, yield, Chemical composition.
\end{abstract}

\section{INTRODUCTION}

Excessive vegetative growth is a frequent trouble observed in cotton fields that may cause high fruit shedding, late maturity and low cotton yield.

Phosphorus $(P)$ is an essential macronutrient required for energy transfer (i.e., ATP and NADPH), which increases carbohydrate transport from leaves to developing bolls. Genetic information (i.e., DNA and RNA), formation of phospholipids and play an important role in membrane integrity, it also plays an important role in induction the balance between vegetative growth and fruiting capacity for rank growth of cotton plants. Phosphorus has attracted a tremendous amount of research effort over the last 100 years but its behavior and availability for crops is still imperfectly understood. It is well known that plants take up phosphorus in smaller amounts than nitrogen or potassium. However, phosphorus is the second key plant nutrient and its many compounds has play important role in cell division, in stimulation of early root growth, 
in hastening plant maturity, in energy transformations within the cells and fruiting and seed production.

Phosphorus foliar spraying has been reported by many workers to increase most of cotton yield characters (Girgis et. al., 1993, Omran et. al., 1999, Wahdan et. al., 2000 and Saleem et. al., 2010).

In recent years, growth regulating substances play an important role in controlling seed germination, vegetative growth, flowering and yield of several crop plants.

Mepiquat chloride (Pix) (1,1- dimethylpiperidinum chloride) is a growth regulator that has been widely used to reduce vegetative growth by decreasing leaf size internode length and increase mesophyll layer which carry chlorophyll, to allow plants to direct more metabolic energy towards the reproductive structure, (Fletcher et. al., 1994). It inhibits the synthesis of the plant hormone gibbrellic acid (G.A.). On the other hand, mepiquat chloride application increased number of open bolls / plant, boll weight, seed index and seed cotton yield per feddan, (Ghourab et. al., 2000 and Singh, et. al., 2009). While, Muhammed et. al., 2007 found that spraying Pix had no significantly effect on lint percentage and seed index. Also, Muhammed et. al. 2001 and Sawan et. al. 2008 found that spraying Pix had no measurable effect on fiber properties.

The present study aimed to evaluate the effect of phosphorus and Pix on Egyptian cotton cultivar, Giza 86 which was cultivated after fallow or/and after Berseem crop.

\section{MATERIALS AND METHODS}

Two field experiments were conducted at Gemmeiza Agricultural Research station, during 2008 and 2009 seasons, to study and evaluate the physiological role of foliar application of phosphorus and Pix in controlling the excessive vegetative growth of cotton plant (Giza 86) especially of those plants which were planted in fertile soils as Gemmeiza Research station, (Table, 1).

Cotton seeds were sown on $1^{\text {st }}$ April and March 30 in 2008 and 2009 seasons, respectively. Experimental unit area was $14 \mathrm{~m}^{2}(4 \times 3.5)$ and contained five ridges. Each ridge was 4.0 meter long, $65 \mathrm{~cm}$ wide with the hills $25 \mathrm{~cm}$ apart on one side of the ridge. Hills were thinned after three weeks from planting to two seedlings. All plants received an adequate amounts of nitrogenous (45 kg/fed.), phosphoric (22.5 $\mathrm{Kg} /$ fed $\mathrm{P}_{2} \mathrm{O}_{5}$ ) and potassium fertilizers (24 kg/fed.) as recommended for cotton variety. All agricultural practices were carried out as usual. Three concentrations of phosphoric acid (85\%), (1, 1.5 and $2 \mathrm{~cm}^{3} / \mathrm{L}$ ) and mepiquat chloride (Pix, $50 \mathrm{~g} / \mathrm{fed}$.), $\left(1,2\right.$ and $\left.3 \mathrm{~cm}^{3} / \mathrm{L}\right)$ were sprayed at pinhead square, start of flowering and peak of flowering stage. 
The experiment was planted in complete randomized block design with 4 replicates. Therefore, the eight applied treatments were as flows:

1- Control.

3- $1.5 \mathrm{~cm}^{3} / \mathrm{L}$ phosphoric acid, $(22.5 \mathrm{~kg} / \mathrm{fed})$.

5- $1 \mathrm{~cm}^{3} /$ L Pix (50 g/fed.).

7- $3 \mathrm{~cm}^{3} /$ L Pix.

Pix).

- Chemical analysis: chlorophyll a and b (Arnon, 1949), carotenoids (Rolbelen, 1957), oil \% and protein \% in seeds were determined according to the methods of

\section{A.O.A.C (1975).}

Five plants were randomly selected in each plot as a representative for chemical analysis of cotton leaves. Leaves from the main stem on the fourth node from the apex were taken after 15 days from foliar application for each treatment.

- Growth characters: final plant height and number of fruiting branches per plant. However, ten plants were also randomly selected in each plot for measuring plant height, yield and yield components.

- Yield and its components: Number of open bolls/plant, boll weight, Relative fruitfulness RF (number of bolls which equilibrium/100 gm of shoot and branches dry weight), seed index, lint $\%$, earliness $\%$ and seed cotton yield per feddan.

- Fiber properties: micronaire value and Pressley index were determined at the Laboratories of Cotton Research Institute according to A.S.T.M. (1975).

- Polyphenols: were determined according to A.O.A.C (1965).

- Total phenols: were determined according to Simons and Ross (1971).

The data of the experiments were subjected to statistical analysis according to Snedecor and Cochran (1981) and the treatment means were compared using L.S.D. values at $0.05 \%$ level of probability.

Soil analysis for the two seasons was carried out according to (2008 - 2009), the results of analysis are shown in Table (1).

Table 1. Analysis of the experimental soil in 2008 and 2009 seasons.

\begin{tabular}{|l|c|c|}
\hline \multicolumn{1}{|c|}{ Properties } & $\begin{array}{c}\text { Value } \\
2008\end{array}$ & $\begin{array}{c}\text { Value } \\
2009\end{array}$ \\
\hline $\mathrm{pH}$ & 7.6 & 8.1 \\
\hline Textural class & Clay lome & Clay lome \\
\hline E.C. $\left(\mathrm{mmohs} / \mathrm{cm} / 25^{\circ} \mathrm{C}\right)$ & 1.2 & 1.1 \\
\hline Available N (PPm) & 22.5 & 25.1 \\
\hline Available P (PPm) & 16.5 & 13.0 \\
\hline $\mathrm{Available} \mathrm{K} \mathrm{(PPm)}_{\mathrm{CaCO}}{ }^{\circ}$ & 362 & 317 \\
\hline $\mathrm{HcO}_{3}{ }^{-}$ & 2.1 & 1.9 \\
\hline
\end{tabular}




\section{RESULTS AND DISCUSSION}

\section{A. Effect of phosphoric acid and Pix on growth characters:}

Data in Table (2) indicate that foliar application of phosphorus and Pix as well as PHX $\left(1.5 \mathrm{~cm}^{3} / \mathrm{L} \mathrm{ph}+2 \mathrm{~cm}^{3} / \mathrm{L} \mathrm{Pix}\right)$ treatments reduced significantly the height of cotton plant at harvest than the control. These results were in the same trend in both seasons. In this respect, Wahdan et. al., 2000), showed that foliar application of phosphorus tended to reduce the excessive vegetative growth of cotton plant, it decreased significantly plant height. And also, Singh et. al. (2009) and Ghourab et. al., (2000) found that plant height was significantly reduced by mepiquat chloride (Pix) application. The decrease in plant height was due to the reduction in length of internodes and the action of pix on growth inhibition is mainly due to its effects on lowering the diffusible auxin level in the plants, cell elongation was inhibited, resulting in reduction of growth in height and width (Fletcher et. al., 1994).

The enhanced effect of phosphorus and Pix application on number of fruiting branches per plant was evident in two seasons (Table, 2). This character was affected significantly by all treatments. Such results may be due to the improvement in plant metabolism. The spraying $2 \mathrm{~cm}^{3} / \mathrm{L}$ phosphoric acid produced higher values of both characters. Omran et. al. (1999) reported similar results. This might be due to the role of phosphorus to divert the plant toward the reproductive phase, because phosphorus has vital role in cell division, cell elongation and stimulate early flowering (Singh, 2003). Regarding fruiting character, Pix application increased number of fruiting branches. Since, Pix used to minimize the vegetative growth. It allows directing more metabolic energy toward the reproductive structure, Flotcher et. al. (1994).

\section{B. Effect of phosphoric acid and Pix on yield and yield components:}

Data presented in Table (2) show that foliar application of phosphorus and Pix on number of open bolls / plant was evident in two seasons. This character was significantly affected by all treatments compared to the control.

Concerning boll weight, results revealed that all treatments did not show any significant effects on boll weight in the first season (2008), but it significantly increased in the second season (2009). In general, boll weight seemed to increase by phosphorus and Pix applications. Omran et. al. (1999), Wahdan et. al. (2000), Saleem et. al. (2010) and reported that boll weight was increased significantly by phosphorus spraying. On the other hand, Abdel-AL (1998), found that boll weight was not significantly affected by Pix treatments. However, Ghourab et. al. (2000) revealed that foliar application of Pix tended to produce the heaviest bolls. 
Table (2) 
In general, seed cotton yield per feddan was increased significantly with the application of phosphorus or Pix at different stages in the two seasons (Table, 2). The highest value of seed cotton yield per fed. was obtained from the combination of phosphorus and Pix $\left(1.5 \mathrm{~cm}^{3} / \mathrm{L} \mathrm{ph}+2 \mathrm{~cm}^{3} / \mathrm{L}\right.$ Pix $)$. The seed cotton yield was exceeded by $25.5 \%$ and $25.8 \%$ in 2008 and 2009 over the control, respectively. The observed increment of seed cotton yield may be a result of the increase in number of open bolls and number of fruiting branches as well as boll weight due to the important role of phosphorus in the physiological processes in cotton plants. It is worth to note that phosphorus foliar spraying has been recommended by many workers to increase seed cotton yield. Wahdan et. al. (2000), Singh et. al. (2009) and Saleem et. al. (2010) found that spraying Pix increased the reproductive growth i.e., boll weight, harvest index and seed cotton yield.

Beside the favourable effects of phosphorus application and Pix on yield, these treatments also showed a significant increase on relative fruitfulness (R.F.) and earliness percentage in the two seasons (Table, 3). It is clear from Table (3) that all treatments had no significant effect on lint percentage and seed index. However, such treatments tended to increase slightly seed index as compared to control, and the results were confirmed in the two seasons. Pix significantly increased the total number of flowers per plant because its decreased the shedding of squares and it reflexed to increased the number of open bolls and added that he treated plant matured earlier and attributed this to earlier cutout of boll-setting, treated plants exhibited a higher rate of boll maturity increase the number and size of bolls as well as seed cotton yield. Muhammed et. al. (2001), Wahdan et. al. (2000) and Omran et. al. (1999) reported that lint percentage was increased significantly by phosphorus spraying. However, Sawan et. al. (2008) found that phosphorus generally had no significant effect on lint percentage, while Saleem et. al. (2010) and Wahdan et. al. (2000), found that foliar application of phosphorus treatments had no significant effect on seed index. On the other hand, Muhammed et. al. (2007), found that spraying Pix had no significant effect on lint percentage and seed index. 
Table (3) 


\section{Effect of phosphoric acid and Pix on fiber properties:}

Data shown in Table (3) reveal that foliage spraying of phosphorus or Pix had no measurable effect on fiber fineness (micronaire reading) and fiber strength (Pressely index). These results are similar to those obtained by Sawan et. al. (2008) and Muhammed et. al. (2001).

\section{Effect of phosphoric acid and Pix on chemical contents:}

Data presented in Figures $(1-2)$ show that most of chemical constituents of cotton leaves responded significantly to the application or phosphorus concentrations and Pix as well as PHX.- Chlorophyll a, Chlorophyll b, Chlorophyll $(a+b)$ and carotenoids were controlled significantly with these treatments. In this respect, Wahdan et. al. (2000), concluded that phosphorus plays a fundamental role in large number of enzymatic reactions that depends on phosphorylation.

In general, phosphorus application at the flowering stage is likely to increase considerably respiration and the reproductive growth, where there was tricking accumulation of total carbohydrates associated with phosphorus application and this may be due to a moderate activation of photosynthesis. The results as shown in Table (4) and Figures (1 and 2) reveal that spraying cotton plants with mepiquat chloride resulted insignificant increase in chlorophyll $a, b,(a+b)$ and carotenoids. Such increase in chlorophyll due to Pix application may increase the absorption of magnesium which if a fundamental element in chlorophyll composition. Ghourab et. al., (2000), reported that mepiquat chloride (Pix) play a role as an activator in the formation of chlorophyll in leaves.

Phenol compounds results in Table (5) and Figures (3 - 4) reveal that application of phosphorus and Pix exerted a significant increase in leaves phenol contents. Polyphenols compounds play an important role in decreasing IAA oxidation in cotton leaves (Abdel-AL, 1998). These results are in accordance with data obtained by Lewis et. al. (1992) who reported that application of plant growth retardants to cotton plants increased phenolic compounds contents is leaves and inhibited vegetative growth. Thus, expending less metabolic energy in building new vegetative structures allowing more available assimilates with cotton plants 
Table (4) 


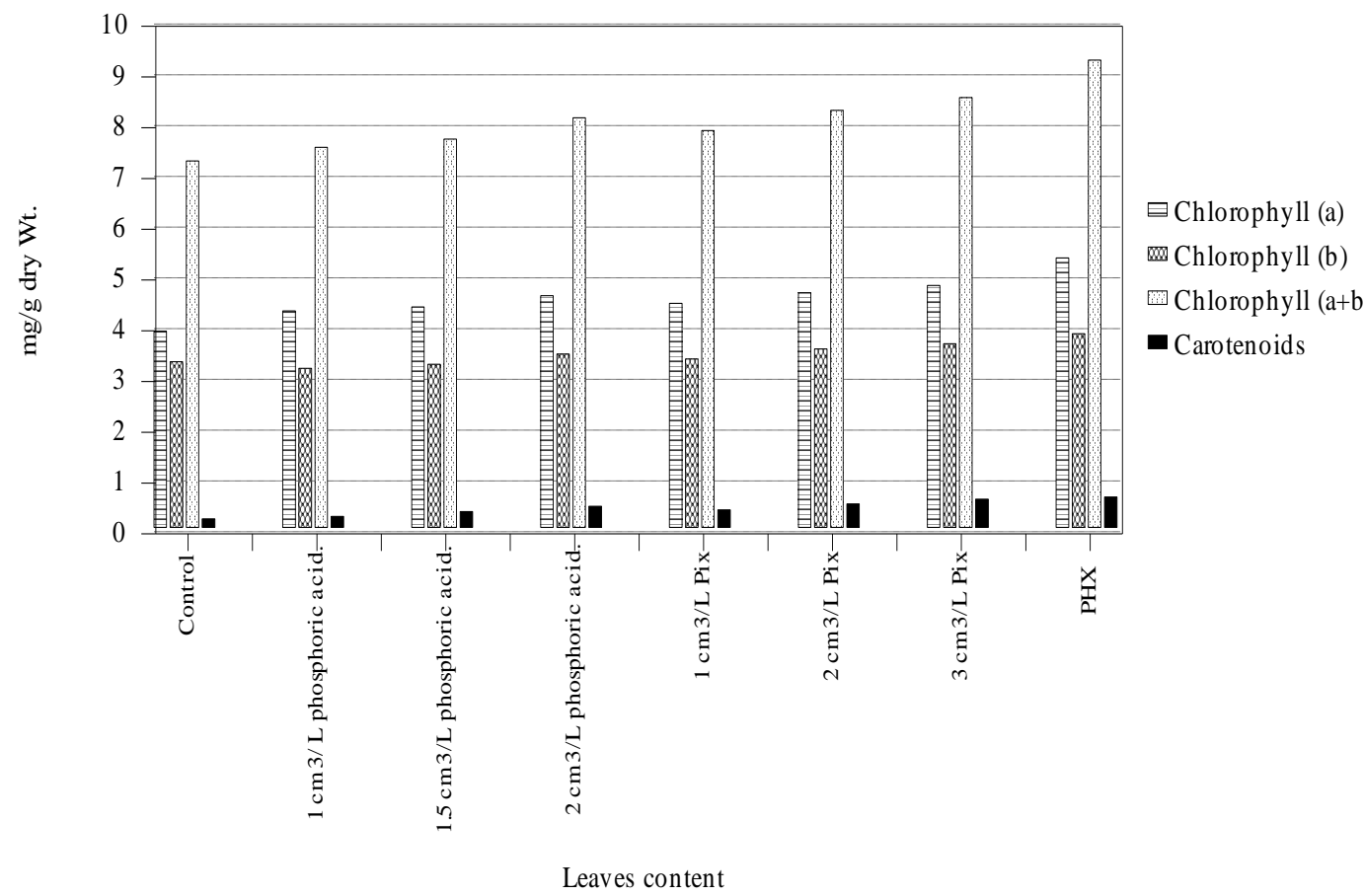

Figure 1. Effect of phosphoric acid and pix on leaves content of chlorophyll and carotenoids during 2008 season.

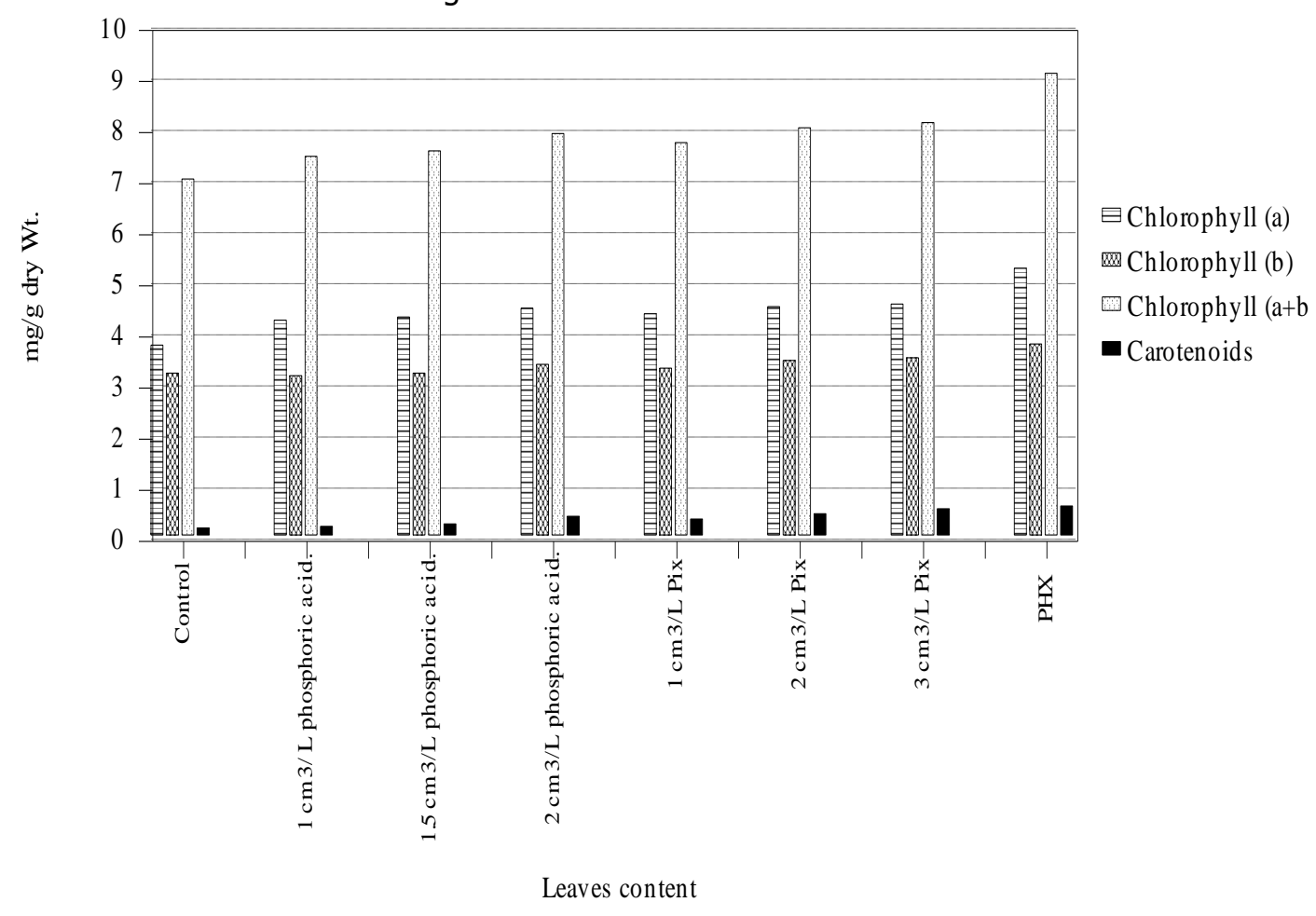

Figure 2. Effect of phosphoric acid and pix on leaves content of chlorophyll and carotenoids during 2009 season. 
Table (5) 


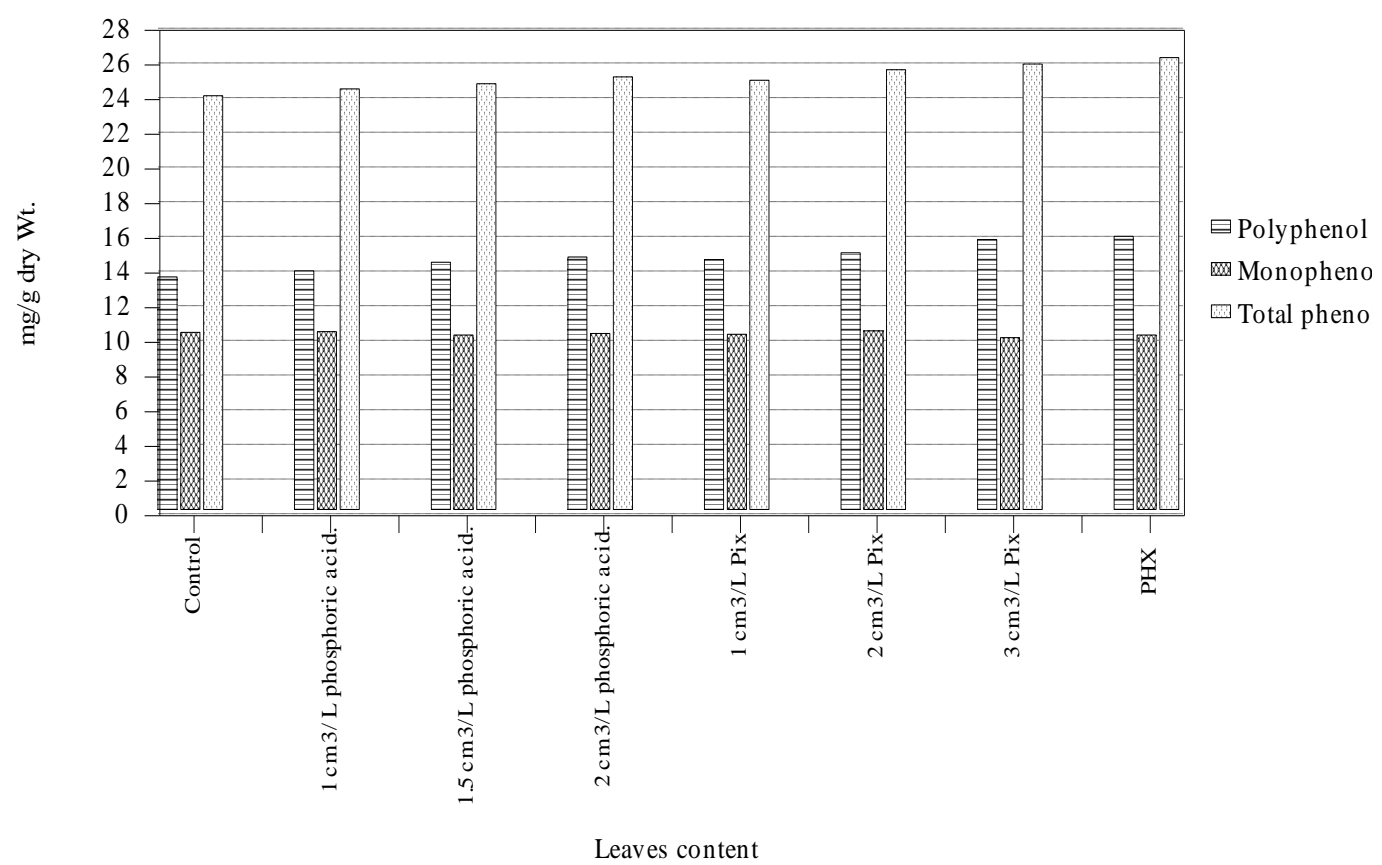

Figure 3. Effect of phosphoric acid and pix on some chemical constituents (phenol) of

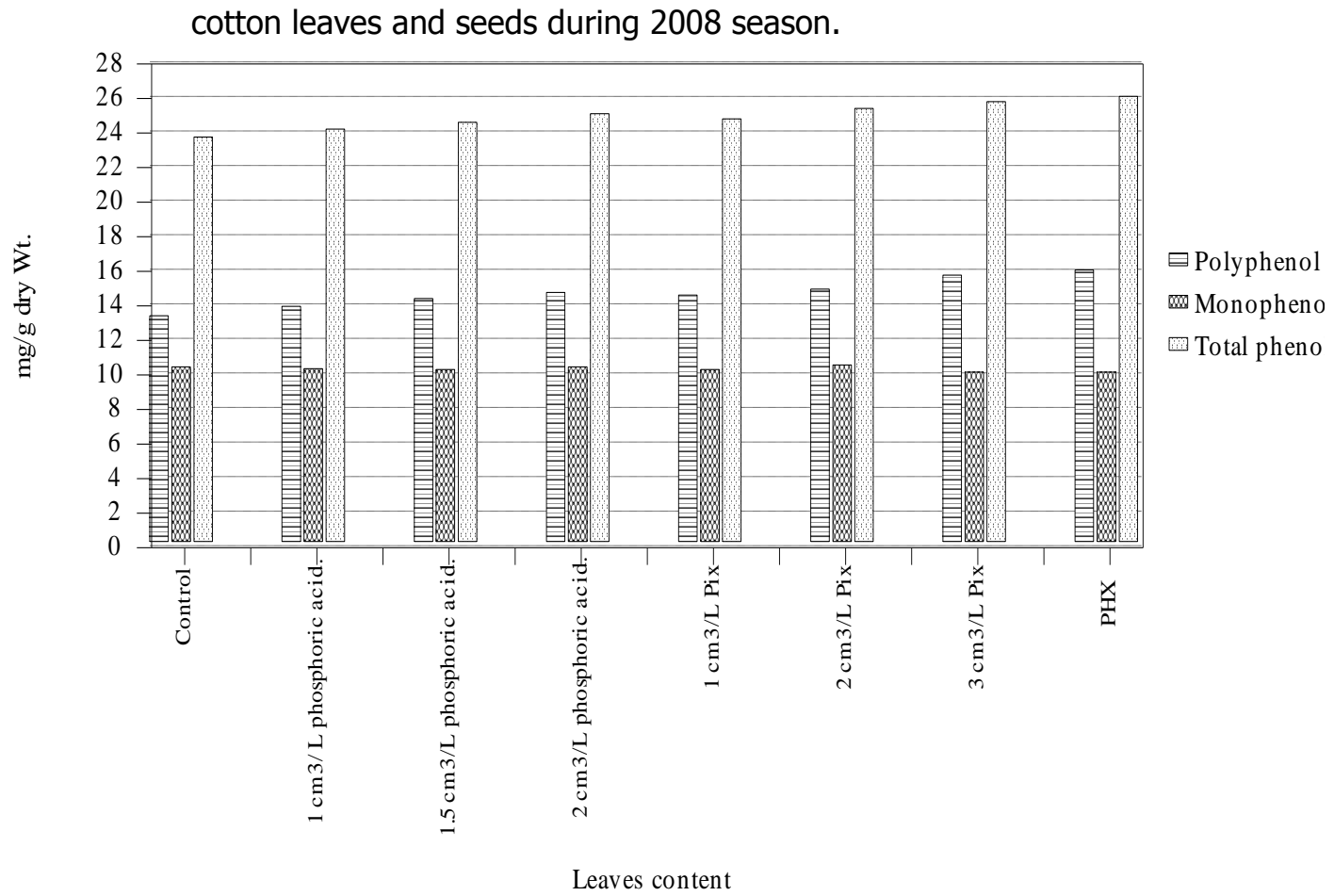

Figure 4. Effect of phosphoric acid and pix on some chemical constituents (phenol) of cotton leaves and seeds during 2009 season. 


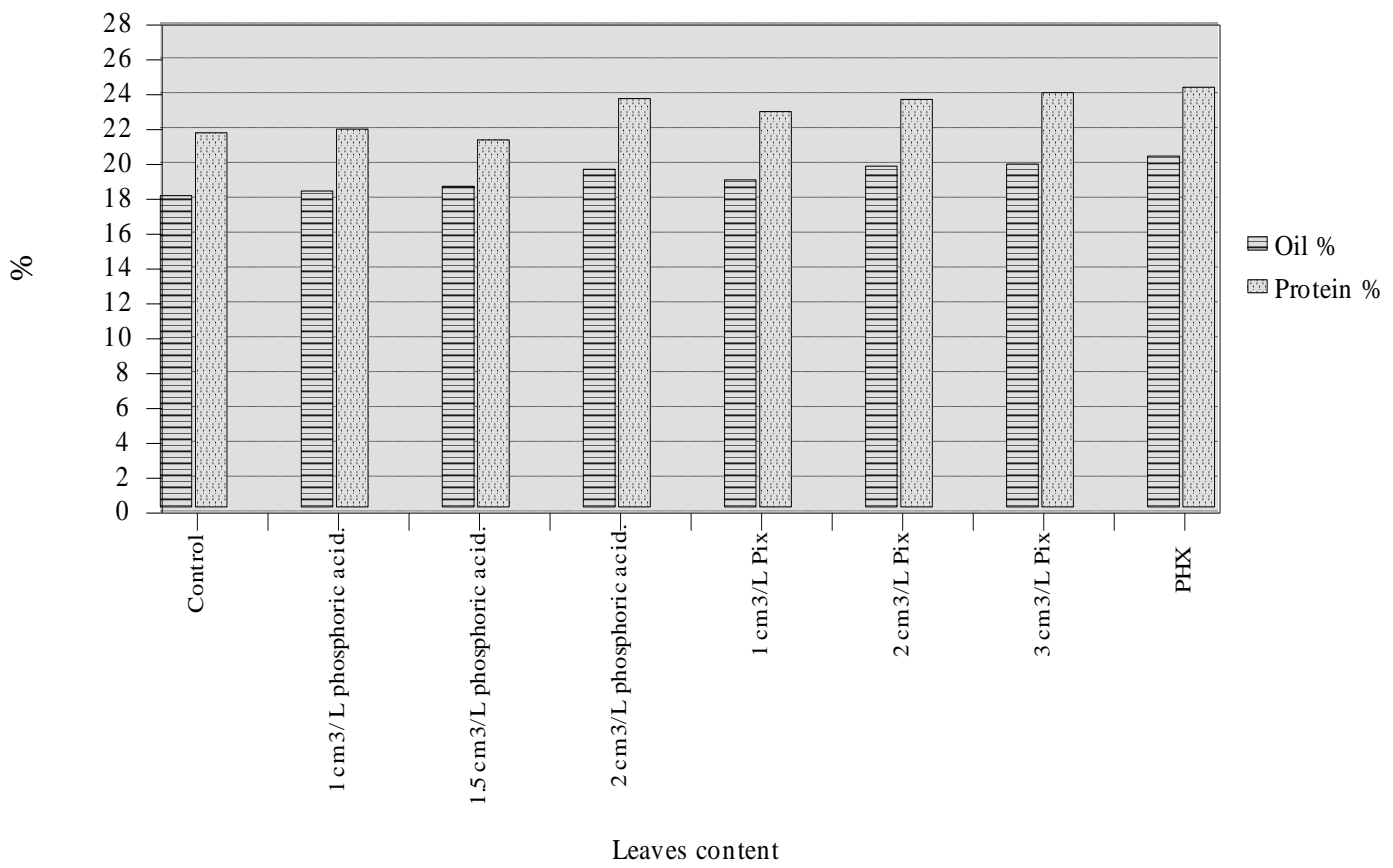

Figure 5. Effect of phosphoric acid and pix on some chemical constituents (Oil and protein) of cotton leaves and seeds during 2008 season.

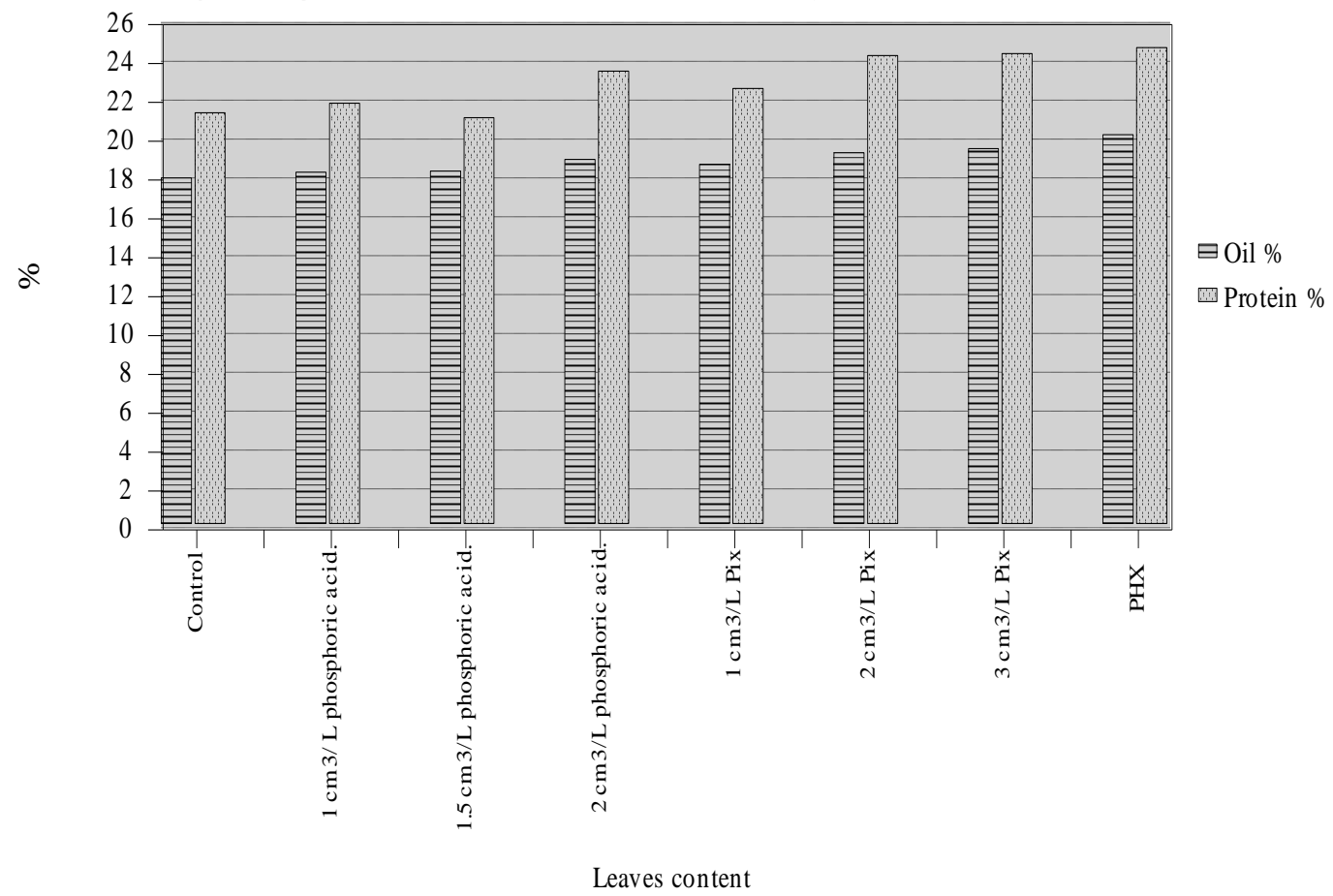

Figure 6. Effect of phosphoric acid and pix on some chemical constituents (Oil and protein) of cotton leaves and seeds during 2009 season.

Seed oil and protein percentages data in Table (5) and Figures $(5-6)$ show that seed oil and protein percentages were significantly increased by the application of phosphorus and Pix. These results are in agreement by Sawan et. al. (2007), who reported that the highest phosphorus concentration gave the best values of seed oil 
and protein percentages. While, Ghourab et. al., (2000), found that oil content in seeds higher due to mepiquat chloride (Pix) in treated plants but it had no significant affect on protein content in seeds. It can be concluded that foliar spraying of cotton plants with $\mathrm{PHX}\left(1.5 \mathrm{~cm}^{3} / \mathrm{L} \mathrm{H}_{3} \mathrm{PO}_{4}\right.$ and $2 \mathrm{~cm}^{3} / \mathrm{L}$ Pix at flowering stage improved performance and increased yield of cotton plants.

\section{REFERENCES}

1. Abdel-Al, M. H. 1998. Respons of Giza 85 cotton cultivar to the growth regulators Pix and Atonik. Egypt. J. Agric. Res., 76 (3): 1173 - 1181.

2. A. O. A. C. 1965 . Association of Official Agricultural Chemists, $7^{\text {th }}$ ed. Washington, DC.

3. A. O. A. C. 1975 . Official and Methods of Analysis of Official Agricultural Chemists. $12^{\text {th }}$ ed. Washington D.C. PP. $94-117$.

4. Arnan, D. I. 1949. Copper enzyme in isolated chloroplasts. Plant Physiol., 24 (1): $1-15$.

5. A. S. T. M. 1975. American society for testing and Materials. Standard on textile Muterials (D 1448-59 and D 1445-67). The Society, Washington, Philadelphia, U.S.A.

6. Fletcher, D. C. J. C., Siler Tooth , E. R. Norton , B. L. Unruchand and E. A. Lowis. 1994. Evaluation of feedback vs. Schedule approach to mepiquat chloride application. Proc. Beltwide Cotton Conf. 1994: 1259 - 1260.

7. Ghourab, M. H. H. , O. M. M. Wassel and M. S. Abou El-Nour. 2000. The effect of mepiquat chloride application on the productivity of cotton plants. Egypt. J. Agric. Res., 78 (3): 1207 - 1218.

8. Girgis, E. A. , A. Abd El-Shafy and M. K El-Kashlan. 1993. Effect of foliar spraying with phosphorus under two levels of nitrogen of Egyptian cotton plant. J. Agric. Res., Tanta Univ., 19 (2): $314-332$.

9. Lewis, E. A. J. C. Silver Tooth and J. E. Malcuit. 1992. Response of upland and pima cotton to multiple application of mepiquat chloride (Pix) ${ }^{\mathrm{tu}}$. Proc. Beltwide Cotton Conf. 1992, (3): 1070 -

10. Muhammed Iqbal, Khezir Hyat and Noor-Ul-Islam. 2007. Cotton response to mepiquat chloride and nitrogen under ultra narrow plant spacing. Asian J. Plant Sci., 6 (1): 87 -92. 26 ref. 
11. Muhammed Iqbal Makhum, Muhammed Nowa A. Malik, Shabab-Md- Dinand Fazal and Illahi Chaudhary. 2001. Effect of phosphorus fertilizer on growth, yield and fiber quality of two cotton cultivars. J. of Res. (Science), Bahauddin Zakariya Univ., Multan, Pakistan, 12 (2): 140 - 146.

12. Omran, A. A. , M. El-Khouly and A. Kh. Ahmed. 1999. Effect of phosphorus and boron spraying on cotton yield. Egypt. J. Appl. Sci., 14 (12): 393 - 402.

13. Rolbelen, G. 1957. Untersuchungen and strohlenin duzieten blatt arbumutonten von arbidopois Thaliana (L.). Verbungsie (Germany).

14. Saleem, M. F. , M. A. Cheema , F. Rasul , M. F. Bila , S. A. Anjum and M. A. Wahid. 2010. Effect of phosphorus on growth and yield of cotton. Crop \& Environment 2010, 1 (1): 39 - 43.

15. Sawan, Z. M. , M. H. Mahmoud and A. H. El-Guibali. 2008. Influence of potassium fertilization and foliar application of Zinc and phosphorus on growth, yield components, yield and fiber properties of cotton (Gossypium barbadense L.). J. PI. Ecol., 1 (4): 259 - 270.

16. Siman, T. S. and A. F. Ross. 1971. Changes in phenol metabolism associated with in clased systemic resistance to tobacco mosaic virus in sum sun NN tobacco. Phytopathology, 61: $1261-1265$.

17. Singh, Devendra, Rakesh Pandey and Vipin Kumar. 2009. Effect of growth retardants on morpho-physiological parameters in cotton under irrigated conditions in cotton-wheat system. Indian J. of pl. physiol., 14 (3): $257-261.9$ ref.

18. Singh, S. S. 2003. Soil fertility and nutrient management. Kalani Publishers, New Delhi, India PP. 38.

19. Snedecor, G. W. and W. G. Cochran. 1981. Statistical Method. $7^{\text {th }}$ ed. Iowa State Univ. Press. Iowa, U.S.A.

20. Wahdan, G. A. , U. A. Saeed and M. H. H. Ghourab. 2000. Role of phosphorus as foliar application at flowering stage on maturation process of cotton plants: 1- Chemical composition, yield components and seed quality. Minufiya J. Agric. Res., 25 (4): $891-905$. 


\section{إستجابة نبات القطن صنف جيزة 86 للرش بالفوسفور ومبيكوات الكلورايد تحت ظروف الأراضى الخصبة}

\section{سناء جمعه جبالى , على السيل الجعبيرى}

قسم بحوث فسيولوجى القطن - معهز بحوث القطن - مركز البحوث الزراعية - مصر

أجريت تجربتان حقليتان بمحطة البحوث الزراعية بالجميزة - محافظة الغربية خلال موسمى

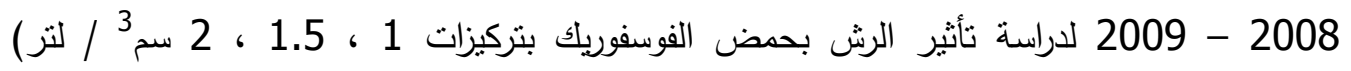
ومبيكوات الكلوريد (بكس) بنزكيزات (1 ، 2 ، 3 سم3 / لتر ) والمركب المشترك بين حمض الفوسفوريك

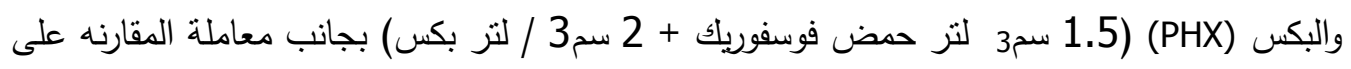
إنتاجية صنف القطن جيزة 86. • أظهرت نتائج الدراسة - أن الرش هيزة بالتركيزات المختلفة من حمض الفوسفوريك و البكس وكذلك

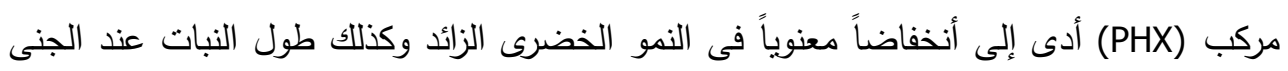

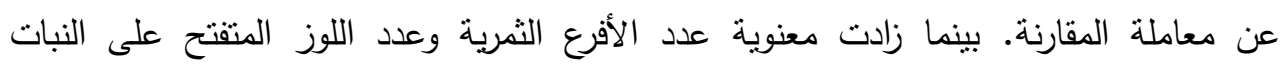

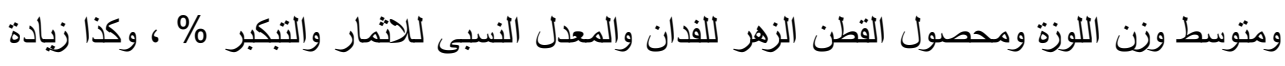

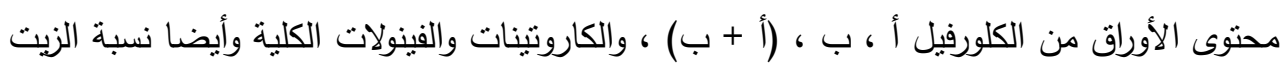

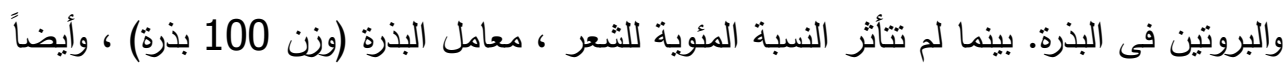

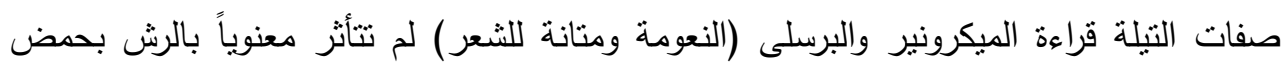
الفوسفوريك والبكس خلال موسمى الزراعة .

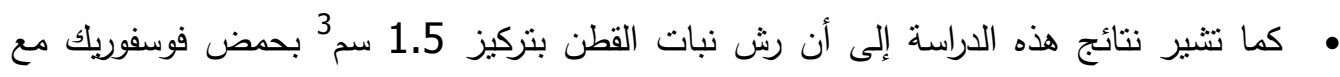

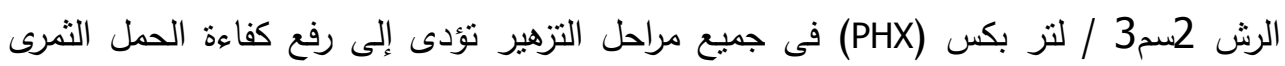
وبالتالى زيادة محصول نبات القطن. 